\title{
Lower Permian bryozoans from southern and central Spitsbergen, Svalbard
}

Hans Arne Nakrem, Błażej Błażejowski, and Andrzej Gaździcki

Acta Palaeontologica Polonica 54 (4), 2009: 677-698 doi: http://dx.doi.org/10.4202/app.2008.0078

Bryozoans from the Lower Permian Treskelodden and Wordiekammen formations of southern and central Spitsbergen

respectively, Svalbard, have been studied. Twenty species are identified, including one new genus, Toulapora gen. nov., with Toulapora svalbardense as type species and one new species, Ascopora birkenmajeri sp. nov. The taxonomic composition is typical Lower Permian, with species in common with Timan-Pechora and the Urals (Russia) and Ellesmere Island (the Canadian Arctic). Growth habits reflect a moderately to deeper shelf environment.

Key words: Bryozoa, Permian, Spitsbergen, Arctic.

Hans Arne Nakrem [h.a.nakrem@nhm.uio.no], University of Oslo, Natural History Museum, PO Box 1172 Blindern, 0318 Oslo, Norway; Błażej Błażejowski [bblazej@twarda.pan.pl] and Andrzej Gaździcki [gazdzick@twarda.pan.pl] Instytut Paleobiologii PAN, Twarda 51/55, 00-818 Warszawa, Poland

This is an open-access article distributed under the terms of the Creative Commons Attribution License (for details please see creativecommons.org), which permits unrestricted use, distribution, and reproduction in any medium, provided the original author and source are credited.

FoF 